\title{
The Impact of Empowering Pisang Mas Banana Farmers through Partnership with PT. Great Giant Pineapple
}

\author{
Nela Sara Gratia ${ }^{*}$, Indra Lestari Fawzi ${ }^{2}$ \\ 12 Master of Social Welfare Studies, University of Indonesia, \\ Jl. Prof. DR. Selo Soemardjan, Pondok Cina, Beji District, Depok City, West Java 16424, \\ Indonesia \\ * Corresponding author. Email: nela.sara@ui.ac.id, Telp: +6285811503728 \\ Received: 28 August 2020; Revised: 04 February 2021; Accepted: 29 March 2021
}

\begin{abstract}
Until now, farmers' welfare has not been given much attention. It can be seen from the fact that a lot of farmers have low income, and a lack of skills and knowledge. One of the ways to improve farmer welfare is to empower farmers, as done by PT. Great Giant Pineapple in Lampung, which has formed a partnership with farmers groups in Tanggamus Regency. This research is aimed to analyze the impact of empowering pisang mas (some type of ladyfinger) banana farmers, through a partnership with the company based on the concept of CSV (Creating Shared Value). This study used a qualitative method, and the informants were selected using the purposive sampling technique. Data were collected through indepth interviews and observations, as well as document studies. The informants consisted of banana farmers who are members of farmers groups, as well as group leaders, the farmers' cooperative management, and the CSV staff. The results of the study indicate that the impact of the partnership program between farmers groups and PT. Great Giant Pineapple can be grouped into economic and social impacts. On the economic side, the impact can be seen in the improvement of farmers' business skills, increase in farmers' income, more job opportunities for the surrounding community, and farmers' access to other institutions. Meanwhile, the social impacts include increase in capacities, skills as well as motivation and confident behavior among farmers, and the strengthening capacities among the farmers groups.
\end{abstract}

Keywords: empowerment, empowerment impact, partnership, creating shared value

How to Cite: Gratia Sara, N \& Fawzi Lestari, I (2021). The Impact of Empowering Pisang Mas Banana Farmers through Partnership with PT. Great Giant Pineapple. JPPM (Jurnal Pendidikan dan Pemberdayaan Masyarakat), 8(1), 106-118. doi: 10.21831/jppm.v8i2.38635

\section{Introduction}

The agricultural sector is a sector that contributes greatly to the economic growth in Indonesia. Based on official data released by Statistics Indonesia, up to the third quarter of 2019, Indonesia has experienced an economic growth of 5.02\%. Statistics Indonesia data also reports that from 2015-2018, based on the distribution, the agriculture, forestry and fisheries sectors are the third highest contributors to economic growth in Indonesia.

For this reason, farmers are an inseparable part of the country's development and economy. Nevertheless, although agricultural land is decreasing in the midst of world development, agricultural business can still be found especially in rural areas. The Official Statistical News on Indonesia's Poverty Profile in September 2019 published by Statistics Indonesia reported that the poverty rate in Indonesia had fallen to $9.22 \%$ or $\mathbf{2 4 . 7}$ million people, with 14.93 million people living in rural areas, suggesting that 
farmers deserve welfare more. This is in line with research conducted in the Gisting district of the Tanggamus regency on chili pepper and cabbage farmers. Despite a good level of productivity in the area, there are still many people who live in poverty due to the low quality of human resources in addition to consumptive behavior among farmers (Hasanuddin et al., 2009).

The agricultural sector itself includes various sub-sectors, such as plantation products, food crops, fisheries, livestock, horticultural crops, forestry, as well as agricultural and hunting services. Based on the 2017 Agricultural Indicators issued by Statistics Indonesia, the contribution of agriculture to gross domestic product in 2017 was $13.14 \%$, of which $1.44 \%$ came from horticultural products. This figure from horticultural products is significant because it has the potential to contribute to employment and therefore, the main source of rural household income, as well (Ministry of Agriculture, 2017). Horticultural crop produce consists of vegetables and fruits, which are in high demand among the people of Indonesia, in addition to staple food crops such as rice or corn. Vegetables and fruits are not only popular in the domestic market, but also have the potential for export trades. In Warta Ekspor, a monthly publication published by the Ministry of Trade, Indonesia is reported to be one of 20 countries with fruit productions in the world trade competition (Ministry of Trade, 2017).

The industrial and trade sectors need to cooperate with farmers and companies that manage and process fresh produce so that they are marketable in both domestic and international markets. Collaboration between companies, the government, and farmers groups is crucial in order to help local products gain a high demand. In this case, corporations can act not only as the collector, processor and distributor of fresh produce provided by farmers, but also play a role in providing education, training, technology transfer, and values to local farmers to improve their skills. Therefore, the quantity and quality of the crops and produce can be increased and give a positive impact on the farmers' income and welfare.

Efforts in improving the welfare of farmers can be done by developing their potential through empowerment programs. Currently, many companies are applying the concept of CSV (Creating Shared Value) in their business strategy. The concept of CSV was first introduced by Michael E. Porter and Mark R. Kramer in 2006. This concept was a result of concerns on the impact of externalities on company productivity, which mostly harmed the surrounding community socially and environmentally. As a result, these emerging social issues require a balanced solution from the company and the community. According to Porter and Kramer, the CSV concept is a policy and practice in the production's operational activities to increase the competitiveness of companies, while stimulating the economic and social conditions of the communities where the business activities are located (Kramer \& Porter, 2019). The development of this concept then becomes important by acknowledging the fact that although not all social issues can be resolved, the application of this concept can provide an opportunity for the community to use their personal skills, resources, and managerial skills to improve their own welfare.

In Indonesia, the CSV program has begun to be implemented by companies for the local community. Research on CSV conducted by the Badak LNG company, for example, aims to increase the welders' capacities in Bontang (Sunaryo, 2015). The program implemented by the company with the application of the CSV concept is a certification program in collaboration with Bontang Welders Association, which 
provides guidance, training, and mentoring as well as establishes workshops for welders to practice and take certification tests. However, this study only shows the application of the concept in the program. Similarly, a study conducted by Prafitri on the implementation of CSV by Nestle on dairy farmers in East Java shows that the company gains more profit than the farmers' community and environment (Prafitri, 2017). Another study conducted by Fitrianti shows that the innovations applied tend to lead towards the interests of the company, although there are still benefits that can be felt by oil palm farmers (Fitrianti, 2017).

Although the implementation of the CSV concept in the context of community empowerment has had varied results (both successes and failures), the trend to use CSV among corporations as a part of their business strategy is growing in Indonesia. This is because the community can immediately feel the impact of the contribution they receive and it can be done in a long term, while the program remains within the scope of the company and benefits the sustainability of the company. There are even institutions/organizations that specifically aim to promote the shared value concept and practice, such as the Indonesian Shared Value Institute, which gives trainings for companies who plan to apply CSV (ISVI, 2019). CSV programs can embrace not only the interests of the company, but also those of the community which is the core of a successful implementation of this concept. In addition, the principle of integrating various parties between business, community, government, and other institutions greatly influences each other to ensure that CSV programs and activities can be implemented well. This aspect is also considered in the study on the collaboration established by Nestle with the Community Development Facilitator Forum and Rural Development to increase the capacities of farmers, as well as small and medium business owners (Farida, 2019). Meanwhile, this study only focuses on the partnership program between the stakeholders.

Past studies on this subject are generally concerned with the program implementation done by a corporation on the community as the program target. In terms of impact, although the community typically responds positively, the company in fact receives more advantages from the program. Little research is done on the impact for the target group, although the community aspect is indeed the most essential component in the success of CSV implementation. In this study, the impacts studied are not based on farmers as individuals, but what they collectively experience and receive as part of empowerment program for the farmers groups as a result of the partnership program with the company.

PT. Great Giant Pineapple (PT. GGP) is one of the companies which uses a partnership approach with the farmers groups in the Tanggamus Regency in their attempt to empower pisang mas (lady finger) banana farmers. PT. GGP is a local company and one of the largest horticultural companies in Indonesia, which produces fruits such as pineapples, bananas, guavas, etc. Lampung was chosen as the research location because of the company's horticultural business and production in Lampung. In addition, based on data obtained from Statistics Indonesia (2019), until 2018 the agricultural sector is the main employment for the people of Lampung aged 15 years and over. The high number of farmers in Lampung also shows that family income which is also related to their welfare depends on the production of the agricultural sector. Tanggamus Regency itself is a great location for plant cultivation due to suitable topography and weather conditions. 
PT. GGP began the program with 7 farmers and eventually ended up with 471 farmers in February 2020. The CSV implementation by the company evidently brings impacts to the farmers. The company's success in applying the CSV concept has earned them the Polaris award for "Redefining Success Generation Community Partnership for Sustainable Growth". In 2019, the company received another award from the Ministry of Industry as a company that develops the Green Industry idea. The outcomes of the CSV initiative from the company show that the program has actual positive impacts for the community and environment.

Based on this background, this study aims to analyze the impact of the empowerment program based on the CSV concept on pisang mas banana farmers in Tanggamus through a partnership with PT. Great Giant Pineapple.

\section{Method}

The method used in the research is a qualitative method with a descriptive approach. According to A. Rubin and E. Babbie, the qualitative method provides an indepth understanding of human experience and behavior through direct theoretical observations of social phenomena that provide a comprehensive perspective for researchers (Rubin, A. \& Babbie, 2011). The research was conducted at Tanggamus Regency, Lampung, which was the region where the farmers who partnered up with PT. Great Giant Pineapple in the empowerment program resided. The source of data was based on the interviews and observations of the research informants, including the pisang mas banana farmers in the farmers groups, the leaders of the groups, the leaders of the packing houses, the cooperative's members/management, as well as the staff/management of the CSV program of PT. GPP in Tanggamus.

The informants were selected using the purposive sampling technique. Meanwhile, the data analysis includes systematic data collection, data reduction, data presentation, and description/verification of conclusions, as proposed by Miles dan Huberman (Walliman, 2011).

\section{Partnership Program and Activities}

\section{Result and Discussion}

PT. Great Giant Pineapple has worked in the agriculture sector, especially horticulture crops, since 1979 in Lampung. In the past, the CSR program done by the company was in the form of charities, such as donating an ambulance car or means of transportation, etc. A partnership-based cooperation began to take place in the Tanggamus Regency in 2013. However, it was not based on the CSV concept, whereas the commodities were papayas and guavas. The partnership cooperation with the farmers was based on business, in which the farmers served as the suppliers who sold their fruit crops to the company through a vendor according to the company standards. According to the CSV management staff, the partnership cooperation in the past did not require a comprehensive training because the commodities were the type of fruits that will be reprocessed by the company. In contrast, farmers today must pay more attention to the quality of the crops because the pisang mas bananas that they supply for the company are the type of fruit that is sold raw (without undergoing any food processing), which means that the quality and the outer appearance of the fruits becomes an important selling point in the market. For this reason, a more comprehensive training 
and transfer of knowledge and technology for the pisang mas banana farming are important in the partnership between the company and the local farmers.

In 2016, PT. GGP launched a partnership program with local farmers based on the CSV (Creating Shared Value) concept. There are three key aspects in the CSV implementation to ensure the achievement of the social and economic values (Porter dan Kramer, 2011). The first one is identifying a potential market and product that are in-demand or has a marketable value. In this study, the product is a horticulture banana crop of the pisang mas variety. Pisang mas bananas are chosen as the commodity for the development based on an assessment process by the company experts. The pisang mas (lady finger) variety has a tender texture, is fragrant, tastes sweet, and is suitable to be cultivated in the Tanggamus area. The planting cycle is also quicker than that of the coffee plants, to the point that they can be harvested every week during the harvest period, which means a higher income per year for the partner farmers. Today, the company's partnership with local farmers has expanded into another addition of variety, namely the barangan bananas. On the other hand, it is also important to not only consider the product, but also the market, so that the farmers have a clear idea on where and how to market their produce. In the partnership, it is clearly stated in the agreement that the company will buy the farmers' crops. Regarding the distribution, PT. GPP relies on their subsidiary branches to market and resell the produce to the wider market. This is in accordance with the first key aspect in the CSV concept which allows the company to explore the farmers' potential to generate a suitable product that has the potential to be developed more.

The second key aspect is to focus on the productivity in the supply chain. In the partnership empowerment program with farmers groups, farmers are the suppliers of produce, whereas the company acts as the market. The produce is supplied to the company through the farmers groups' cooperative. In this scheme, there is no need for farmers to search for the market or pay for transportation costs to sell their produce. This is because the cooperative is the one who will come and collect the produce from the farmers and bring them to the packing houses. Afterwards, the company will market them. This addresses the second key concept of CSV, which is about a more effective and efficient supply chain from production to marketing process. As a result, this system has simplified the older way of trading system and cut the farmers' expenses.

The last key aspect that is also quite crucial is the empowerment of the surrounding local groups because the support of local groups will determine the productivity level and sustainability of the partnership between company and farmers groups. For this reason, PT. GGP formed farmers groups after introducing the partnership program to farmers. The farmers groups are not only an important factor in the success of CSV implementation, but also allow the transfer of knowledge, skills, and technology to be easier among the learning farmers. The formation of a farmer business cooperative is also essential as it is managed by the farmers groups. This allows farmers to be actively involved in the empowerment program/activity and decision-making process in the cooperative. The cooperative also makes it easier to sell and supply the pisang mas banana crops to the company legally.

According to Heifer International (2014), the difference between CSV and CSR (Corporate Social Responsibility) is that the program is initiated by the director which is delegated to the executive team as a part of the company's sustainability program that work together to discuss the strategies. 
The partnership program initiated by PT. GGP was founded on the director's intention to contribute to the surrounding community, so that the company's presence can be felt by the community instead of profiting on their own. The director has a particularly important role, because the program development, including all the activities in the program, is a part of the company's business strategies as a whole. The program financing is a part of the company's operational expense, and not separated as a program that is out of the company's business. Therefore, the economic and social values are shared between the community and the company. In fact, according to the CSV management of PT. GGP in Tanggamus, compared to the profit of the entire production of the company, the profit generated from this program is in fact not particularly significant. Nevertheless, profit was never the main objective as the initial goal was to improve the farmers' welfare.

The partnership program between the company and farmers involves the member recruitment, the development of farmers groups and cooperative, training and learning on crop cultivation, the establishment of packing houses to ensure the produce is ready to sell, and establishing a stable market and price for the partner farmers.

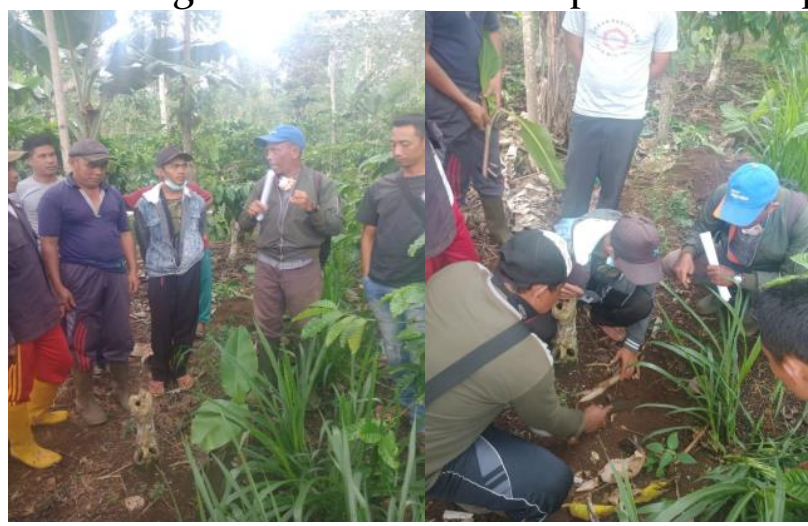

Figure 1. Field training at one of the farmers' farm

Figure 2. Hands-on practice assisted by a facilitator

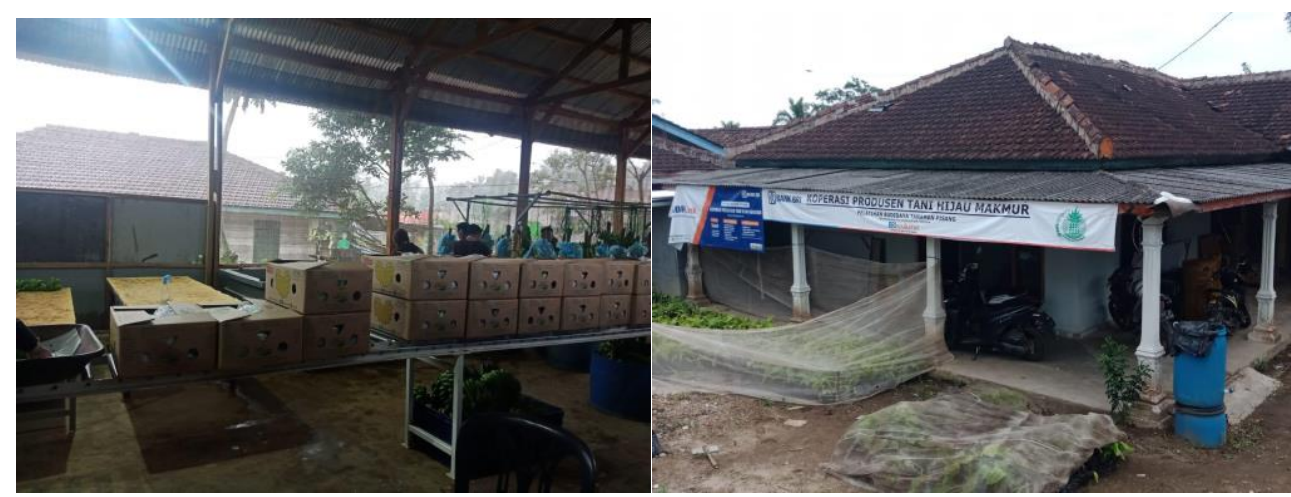

Figure 3. Hijau Makmur Farmers' Cooperative

Figure 4. One of the packing houses at the Ulu Belu district

The packing houses are not owned or managed by the company entirely. Some packing houses are built due to partnership between farmers and the company. Nevertheless, the field operation of the packing house is still assisted and supervised by the company's official staff. The partnership program is also supported with a 
cooperation between the company and the government that endorses the program by providing farming supplies, such as fertilizers and pesticides.

In this partnership program, partner farmers are divided into 2 groups, namely farmers who get facilities and those who do not (no facilities). Farmers who receive the facilities are farmers who meet the criteria for Bonded Zone Facilities, which refers to farmers with monoculture farms. As Tanggamus Regency is a bonded zone, partner farmers are aided by the company with temporary facilities in the form of fertilizers and pesticides. The facilities come from the company as they have an advantage in tax reduction of imported goods; however, they will be billed when exporting goods. Data on bonded zone farmers who are eligible for the aids are collected, and there will be price adjustments for partner farmers who receive such facilities. On the other hand, those with intercropping farms may not receive any facilities as they are not eligible for the bonded zone facilities; however, they can obtain the facilities through the farmers groups and cooperative. Because the cooperative consists of farmers groups, they may propose a list of farmers who are asking for government aids.

From the various activities mentioned, it is clear that the partnership program focuses on the empowerment of local farmers groups. As previously explained, the empowerment of local groups greatly affects the success of CSV programs. All activities done by PT. GGP with the pisang mas banana farmers in the Tanggamus Regency focus on strengthening the farmers groups. In the partnership, it is easier to promote various aspects of empowerment through groups. For example, the success of one group with increased income will attract other farmers who become interested in joining the partnership program and becoming a part of the group. Moreover, training and learning activities are more effectively done in groups, especially because the farmers in Tanggamus consider helping one another as one of the most important aspects in the community.

Empowerment itself is an effort to enhance the power of disadvantaged groups to have the opportunity to make their own choices in life through policy making, social action, and education (Adi, 2012). In this case, the impact of empowerment is in line with the concept of CSV itself, meaning that there is an impact that directly benefits the community, especially the pisang mas banana farmers groups as the program partners, in terms of economic and social aspects. The impact of this partnership program can be seen from the economic and social aspects of farmers.

\section{Economic Impacts}

Economic conditions are often associated with the financial capacities. Economic condition refers to the ability to have the opportunity to meet financial needs for him or herself, a family, or a group of people. The economic impacts felt by farmers groups are related to better businesses, income levels, to accessibility to information or financial sources. This is also in line with the goal of community empowerment as pointed out by Mardikanto and Poerwoko (2012) (Hamid, 2018). The analysis of the economic impacts is seen based on the changes felt by farmers financially before and after becoming the company partners. Conditions that change as an economic impact on farmers are as follows. 


\section{Better Businesses}

Previously, farmers did not really understand about the appropriate business system, because they only thought about cultivating their land. When the harvest period is over, there is no clear record of the amount of production, the number of crops sold etc., as they just sell the produce directly to middlemen. In the partnership, farmers do not have to worry about marketing their crops. They are trained and required to submit clear records and data on their production as an assessment indicator on the benefits they receive as partners. In addition, farmers also receive training on how to become entrepreneurs. Farmers who are group leaders or managers of the packing houses also have the opportunity to learn how to develop their business better. An improved business means an increased income for the community. From the perspective of empowerment, the farmers' improved businesses show that they have used and developed their potential so that in the future they can not only produce, but also have the ability to run and process their production for the better.

\section{Better Income}

In every empowerment activity, especially in relation to productions, the increase in income is the most noticeable change that can be seen and felt by the participants. The majority of farmers who are currently partners of the program have previously worked as farmers. However, in the past, they still planted many types of produce or crops, such as rice, sweet corns, papayas, coffee, and so on, depending on the conditions or the farming trends in their surroundings, ultimately affecting their sales and economic income. Prior to the program, farmers used to sell their crops to middlemen who were willing to accept large parties and sometimes to local markets. However, the price and sales were in danger of being manipulated depending on the supply, hence resulting in market and price uncertainties.

Not all farmers who are partners with PT. GPP has a monoculture farm (growing one type of produce). Some of them grow several types of crops on one land (intercropping), such as coffee farmers who reside in the Ulu Belu District. Coffee beans actually have the potential to increase the farmers' income as they have a good market and a good price although the farmers still must sell them to the middlemen who will determine the price. However, the plant has a long life cycle, which means that the farmers only work for a certain period of time in one year. Typically, the farmers need three months to process the beans and merely wait for the crops for the rest of 9 months, hence affecting their daily income in one year, especially for farmers whose main occupation is farming and has no other skills or jobs. The disadvantage is earning income and harvesting once a year, and not using the rest of the year to do productive work.

With this partnership, in accordance with the contract, the farmer has a guaranteed reliable price from the company that does not change depending on the circumstances or the amount of existing production. Therefore, the farmers can calculate their income every time they harvest, and no longer need to guess or be afraid of having the price manipulated. Under the contract, the company is obligated to buy the harvest from the partner farmers, regardless of the amount.

The increase in income obtained by farmers is not only due to the price certainty. The banana harvesting system in fact occurs once a week, which means that farmers always have a regular income every week for their family needs. For example, one of the farmers named Farmer T owns a farm with 500 banana trees. After about 8-9 months of 
growing and cultivating, the first harvest is about 1 quintal, which is sold at a price of IDR 2,500 per kg as agreed in the contract. Until last year, he was able to harvest up to 3-5 tons. In the past, the farmer grew eggplants when the price fell to IDR 500 per $\mathrm{kg}$ (as set by the middlemen) due to overproduction. Compared to the deal with PT. GGP, he has managed to improve his income significantly, especially as the income received by partner farmers is the net income due to the absence of transport costs or any other additional costs. In addition, farmers receive many aids in the form of seedlings, fertilizers, pesticides, even medicines.

This confirms that the increase in income among farmers is not only due to the reduction in operational costs and the long supply chain they must comply before becoming partners, but also due to the improvement in the produce's quality and quantity. The result of education and training has proven to improve the selling point of the farmers' product. Moreover, the stable price certainty guaranteed by the company has an instrumental role in the farmers' increased income.

\section{Job Opportunities}

Not all partner farmers do farming as their main occupation. Based on an interview with one of the group leaders, many of them also work as teachers, tree fellers, etc. The partnership program has opened a job opportunity for farmers who need additional income. This also applies for those who initially had no jobs, as they are now able to cultivate their land as banana farmers.

In addition to providing job opportunities for farmers, the partnership program also offers opportunities for the community members in the surrounding area. For instance, due to the need for packing houses on a certain location, whether independently or semi-independently with partner farmers workers, there is a demand for workers to build and operate the packing house daily. Therefore, not only helping the welfare of the farmers, the partnership and aids in this program are also able to reduce unemployment rate in the surrounding area.

\section{Better Accessibility}

Due to the development of farmers groups and cooperative as the point of attraction, it is now easier for the community to build partnerships with other institutions, including financial institutions. Although the cooperative currently serves as a body to facilitate the trade between the farmers and company, there has been discussions among the cooperative managers to extend and develop the cooperative's function into other services such as loans, etc. Nevertheless, the cooperative has helped the farmers groups to obtain government aids such as fertilizers and pesticides, and even attract a prominent financial institution such as the Bank of Indonesia to build a partnership with them. In this case, the company collaborates with the bank to ensure that the payment transfer to farmers may be done efficiently. This is one form of better accessibility for the farmers to financial institutions.

\section{Social Impacts}

CSV programs truly put the emphasis on the relationship between economic and social values, because of the belief that the two aspects are interdependent and inseparable from one another. The CSV implementation is considered a success when the community is strengthened above other things, namely by making them the partner 
of the company in order to improve their quality and efficiency. As long as the program refers to this notion, the impacts will surely cover not only the economic aspect, but also the social aspect of the community.

Social life is highly related to social processes which indicate that there is a mutual relationship between one another that impact changes in the community life (Iskandar, 2017). The social impacts may be directly affected through the process of friendship, family and work, as well as indirectly through print and electronic media (Juariyah, 2010). The social impacts experienced by the banana farmers groups in Tanggamus after being the partner of PT. GGP are described below.

\section{Improved Capacities and Skills}

In the empowerment activities of the partnership, farmers receive assistance, training, and guidance. Training and guidance are delivered by facilitators for the individuals or groups. Individually, facilitators conduct monitoring on the partner farms, and assist the farmers, for example, when the plant has a disease, or by offering solutions to their problems and reminding them to care for the banana plants. In this case, the facilitators not only give knowledge in terms of banana cultivation, but also motivate them to work harder. For the groups, the facilitators usually hold a field training. The sub-coordinator of the farmers group will make an appointment with the facilitator to conduct a training with materials that the farmers need. According to farmers, the guidance and training that are done in groups are more effective because it is directly done in one of the members' farms with hands-on practice to deal with the problem. This shows that there is a greater sense of trust among the farmers, and that they are able to influence each other collectively. Therefore, it is important for trainers/facilitators to provide clear knowledge for farmers and motivate them to keep building their capacities.

Farmers also admitted that since joining the program as partners, their knowledge of the cultivation of pisang mas banana plant has improved. Even though they are farmers, they were not initially aware of the science of cultivation and used to deal with issues such as diseases merely through assumptions. Now that they have learned the appropriate ways, they can solve the problems accurately.

In addition to knowledge on cultivations and farming, the partner farmers also received other training materials, such as on finance and cooperative management. In 2019, PT. GGP utilized digital technology to monitor farmers' development and real-time cultivation data by launching the e-grower application. This can also be seen as an attempt to empower farmers to be more technologically literate. Although farmers who have received training and use this application claim that it is useful, it is still considered a bit complicated, especially by those who are of old age.

From this perspective, the impact of farmers' improved capacities and skills serves as an instrument for the achievement of the empowerment goals. Using their capacities, farmers are empowered to be more independent and decide the continuity of their life in the future.

\section{Confidence in Behavior}

Successful partner farmers have now become more confident, especially when the government pays attention to them as shown by a visit from the ministry. This further motivates each farmer to improve their abilities, quality, and productivity. They 
also have a higher sense of discipline, as well as responsibility toward the community and environment.

\section{Community Involvement in Organizations}

The formation of farmers groups leads to closer relations between their members. The close relations between farmers in the group have raised an awareness to help each other and share information. One farmer even said that there is only healthy competition in the group, where each farmer motivates each other to take good care of their crops, so that they can harvest more. With the achievements of these successful farmers, they can then create an impact on other communities. More and more farmers are motivated to become partners because they see the success of farmers who have become partners. The effect of closeness in the group can be seen by the increased number of partner farmers of PT. GGP up to January 2021, which reached 600 people.

\section{Conclusion}

The impact of the partnership program based on the research findings on the farmers groups in Tanggamus can be seen from the economic and social aspects. This is in line with the creating shared value (CSV) principles, in which a company attempts to explore and develop the potential of a community for sharing economic and social values. The economic impact can be assessed from the improved business skills of the farmers, their increased income, and more employment opportunities in the site of the empowerment program. Moreover, the program also makes it easier for partner farmers to access other institutions, such as banks. Meanwhile, from the social perspective, it can be observed that farmers have higher capacities and skills, motivation and confidence, as well as improved abilities and closeness or bond with their peers. From the social point of view, in addition to the farmers' skills to produce bananas with adequate quality and quantity, the strengthening of the farmers groups holds an instrumental role in the success of the partnership program and its development.

It is suggested that the partnership program improve the human resources aspect by recruiting more field trainers/facilitators. The addition of more trainers is necessary due to the increasing number of the partner farmers and increasing distance between farms, which affects the time and number of meetings. It is particularly important to maintain communication and prevent a sense of neglect among the farmers. Another suggestion is to optimize the function of the cooperative so that farmers who do not receive any aid can still be helped by the cooperative system by providing a saving account.

Lastly, it is important to optimize the use of the e-grower digital application as it is only available to bonded zone farmers. This has become an issue as most of them belong in the older age group and therefore are having difficulties with adapting new technology. For this reason, the program must target younger farmers who are more familiar with new technology.

\section{References}

Adi, I. R. (2012). Intervensi Komunitas dan Pengembangan Masyarakat (Sebagai Upaya Pemberdayaan Masyarakat). Raja Grafindo Persada.

Bryman, Alan. (2012). Social Reseach Methods. Edisi Keempat. New York: Oxford University Press. 
Farida, H. N. (2019). “CSV DAN EKONOMI KREATIF” ( Studi Kasus Tentang Partnership FFPM dan PT Nestle Indonesia Dalam Pengembangan Ekonomi Kreatif di Desa Waturejo Ngantang). 13(6), 97-100.

Fitrianti, W. (2017). Pengembangan Model Creating Shared Value Melalui Pembinaan. Seminar Nasional Penerapan Ilmu Pengetahuan Dan Teknologi 2017, August.

Hamid, H. (2018). Manajemen Pemberdayaan Masyarakat.

Hasanuddin, T., G, D. G., \& Endaryanto, T. (2009). Akar Penyebab Kemiskinan Petani Hortikultura di Kabupaten Tanggamus, Propinsi Lampung. Agrikultura, 20(3), 164170. https://doi.org/10.24198/agrikultura.v20i3.947

Iskandar, D. (2017). Kondisi Sosial Ekonomi Masyarakat Petani Serai Wangi (Cymbopogon Nardus) (Studi di Gampong Terangun Kecamatan Terangun Kabupaten Gayo Lues). 2, 944-965.

ISVI. (2019). Shared Value Indonesia. https://www.sharedvalueindonesia.com/

Juariyah, B. dan S. (2010). Jurnal Ekonomi \& Pendidikan, Volume 7 Nomor 1, April 2010. Jurnal Ekonomi E Pendidikan, 7(April), 58-81.

Kementerian Keuangan. (2018). Peraturan Direktur Jenderal Bea dan Cukai tentang Tata Laksana Kawasan Berikat.

Kementerian Perdagangan. (2017). Warta Ekspor: Potensi Ekspor Buah Tropis Indonesia. Warta Ekspor: Potensi Ekspor Buah Tropis Indonesia, 7, 1-20. http://djpen.kemendag.go.id/app_frontend/documents/index/year:2017/type:113

Kementerian Perindustrian. Siaran Pers: Industri Berperan Penting Serap Bahan Baku dan Tenaga Kerja Lokal. Diambil dari https://kemenperin.go.id/artikel/19934/Industri-Berperan-Penting-Serap-BahanBaku-dan-Tenaga-Kerja-Lokal

Kementerian Pertanian. (2017). Laporan kinerja Direktorat Jenderal Hortikultura TA 2017. http://hortikultura.pertanian.go.id

Kramer, M. R., \& Porter, M. (2011). Creating shared value. FSG.

Kramer, M., \& Porter, M. E. (2019). Creating shared value. Harvard Business Review, February, 327-350. http://www.hks.harvard.edu/mrcbg/fellows/N_Lovegrove_Study_Group/Session_1/Michael_Porter_Creating_Sha red_Value.pdf

Neuman, W. L. (2014). Social Research Methods: Qualitative and Quantitative Approaches. Edinburgh: Pearson New International Edition.

Porter, M. E., \& Kramer, M. R. (2019). Creating shared value. In Managing sustainable business (pp. 323-346). Springer, Dordrecht.

Prafitri, R. (2017). Creating Shared Value (CSV) in East Java, Indonesia: A critical analysis of CSV impacts on dairy farming communities.

Rubin, A. \& Babbie, E. (2011). Research Methods for Social Work. Linda Sshreiber.

Sunaryo, B. (2015). Implementasi Creating Shared Value Badak LNG dalam Program Peningkatan Kapasitas Tukang Las (Welder) di Kota Bontang. Jurnal Studi Manajemen Organisasi, 12(1), 21-30. https://doi.org/10.14710/jsmo.v12i1.8848

Statistik, B.P. (2018). Statistik Perusahaan Hortikultura dan Usaha Hortikultura Lainnya. Diambil dari http://bps.go.id

Statistik, B. P. (2018). Indikator Pertanian 2017. Diambil dari https://www.bps.go.id.

Statistik, B. P. (2019). Kabupaten Tanggaus dalam Anka 2019.

Statistik, B. P. (2019). Provinsi Lampung dalam Angka 2019.

Walliman, N. (2011). Research Methods: the basic. Routledge. 
JPPM (Jurnal Pendidikan dan Pemberdayaan Masyarakat), 8 (1), 2021 - 130 Nela Sara Gratia, Indra Lestari Fawzi

---12015). Community Empowerment Model, diakses dari https://www.stakeholderdemocracy.org/wp-content/uploads/2015/o4/CEMAbridged-New-cover.pdf 